the ceiling. The tiers and access gallery at the back are covered in grey marbled plastic flooring, with gold-coloured carpet on the three access stairways and blue carpet fronting the stage, the curtains of which are in gold. Hardwood strip has been used in the floors of the exhibition halls and travertine for the foyer. The 'flying' staircase is finished with hardwood treads with rubber inserts and aluminium; plate glass and plastic have been used for the balustrade. The architect has designed an appropriately carved teak door for the emergency exit. The designs begin at the base with early forms of life and fossils, pass up to various animals and man, show locomotives, telephones and television sets, and lead to a top row of aeroplanes, sputniks and an atomic explosion. The 'finale' is a row of question marks.

The exhibition halls are heated by low-pressure water coils contained within the floor. Background heating for the theatre is provided by coils behind the stage front and this will be supplemented when the hall is in use by warmed air introduced through the slats on the walls near the stage and extracted at the ceiling below the projection room. The 16-mm. projector is sited in a special room reached by a passage above and behind the auditorium. The building could well have taken a full-size projector, but in view of the difficulty of getting documentary films suitable for educational purposes, the smaller size had to be chosen.

The façade of the new extension is spectacular and modern, yet it provides a pleasing gradation with its neighbours. The bastion-like central mass consists of plain ribs of cream-coloured sandstone, reminiscent of a clinker-built boat, and standing on a simple polished granite base. In the lower portion of the sandstone are a few ovoid windows.

The curved central mass is flanked by two unoqual flat walls, that to the east being smaller and having its square sandstone blocks split into two facets angled diagonally, so as to yield an attractive shadow pattern. The greater flank to the west is framed in square sandstone blocks with alternate ones set back to provide a different pattern, but the main face is a rectangular aluminium frame with a slightly arched doorway in the centre surmounted by five tiers of plain glass panes, the horizontel crossings marked by narrow bars which combine decoration with utility in supporting window cleaners. Through the glass, the stair landings add a decorative motif. The architect was Stewart Sim, a senior architect of H.M. Ministry of Works, and the contract was carried out by Thaw and Campbell, Ltd., Glasgow, at a cost of approximately $£ 120,000$. Thus the Royal Scottish Museum displays the march of time in its architecture and its furnishings -in its exhibits as well-over a full century.

\title{
CANCER RESEARCH IN THE UNIVERSITY OF PERUGIA MEDICAL SCHOOL
}

\author{
BY PROF. LUCIO SEVERI \\ Director
}

$\mathrm{O}^{\mathrm{N}}$ June 26, the occasion of the centenary celebrations of the chair of morbid anatomy of the University of Perugia, Dr. Thelma B. Dunn, head of the Cancer Induction and Pathogenesis Section, National Cancer Institute (U.S.A.), opened at Monteluce an extension to the Division of Cancer Research, University of Perugia Medical School.

The ceremony included a visit to the new animalhouse and the remodelled older one, on the main floor, in which normal work was in progress. The guests consisted essentially of the participants of the international conference on the "Morphological Precursors of Cancer". At the opening of the extension, all the doctors honoris causa of the University of Perugia Medical School were present, including Prof. A. Haddow, director of the Chester Beatty Research Institute, London; Prof. J. W. Orr, director of the Department of Pathology and Cancer Research Laboratories, University of Birmingham; Prof. J. J. Bittner, Division of Cancer Biology, University of Minnesota, Minneapolis; Dr. L. C. Strong, director of the Biological Section, Roswell Park Memorial Institute, Springville; Dr. J. R. Heller, president of the Memorial Sloan-Kettering Cancer Center, New York; Prof. C. Krauspe, director of the Institute of Morbid Anatomy, University of Hamburg; Prof. V. R. Khanolkar, vice-chancellor of the University of Bombay; and Prof. T. Yoshida, dean of the Faculty of Medicine, University of Tokyo.

The extension was designed by Prof. G. Nicolosi, Rome, and the work was carried out under the direction of Dr. G. Castori, Perugia, being erected by Messrs. Fioroni, Perugia, at a cost of 50,000,000 lire. The new accommodation doubles the previous floor area and makes the Division the largest and best equipped organization of its kind in Italy.

The extension consists of four storeys of concretecased steel-framed structure, faced with grey-coloured plaster. The various floors are formed with pre-cast concrete flooring units. The various services to the laboratories, which include hot and cold water, gas, electricity, compressed air, vacuum and steam, are visible, not concealed. In this way easy access is possible to the various services and pipe-lines when it is desired. Each floor is served by an automatic electrically operated passenger lift. The new building is linked with the older Division of Cancer Research by an underground passage, and contains extensive animal-house accommodation and laboratories for virology, tissue culture and cytogenetics.

The main financial responsibility of the Division of Cancer Research has always been borne by the University of Perugia. Additional funds are provided by the National Cancer Institute of the U.S. National Institutes of Health, and to a lesser, but valued, extent from the Lega Italiana per la Lotta contro i Tumori, Consiglio Nazionale delle Ricerche, Farmitalia Milano, and from other private Italian benefactions.

It is only since the Second World War that the idea of a Division of Cancer Research in the University of Perugia was conceived. But it was several years before the plan could be carried out. On November 30, 1952, the Minister of Public Education, on the occasion of the opening of the academic year, announced the establishment of a University Division of Cancer Research at Perugia. In the first building were established an animal 


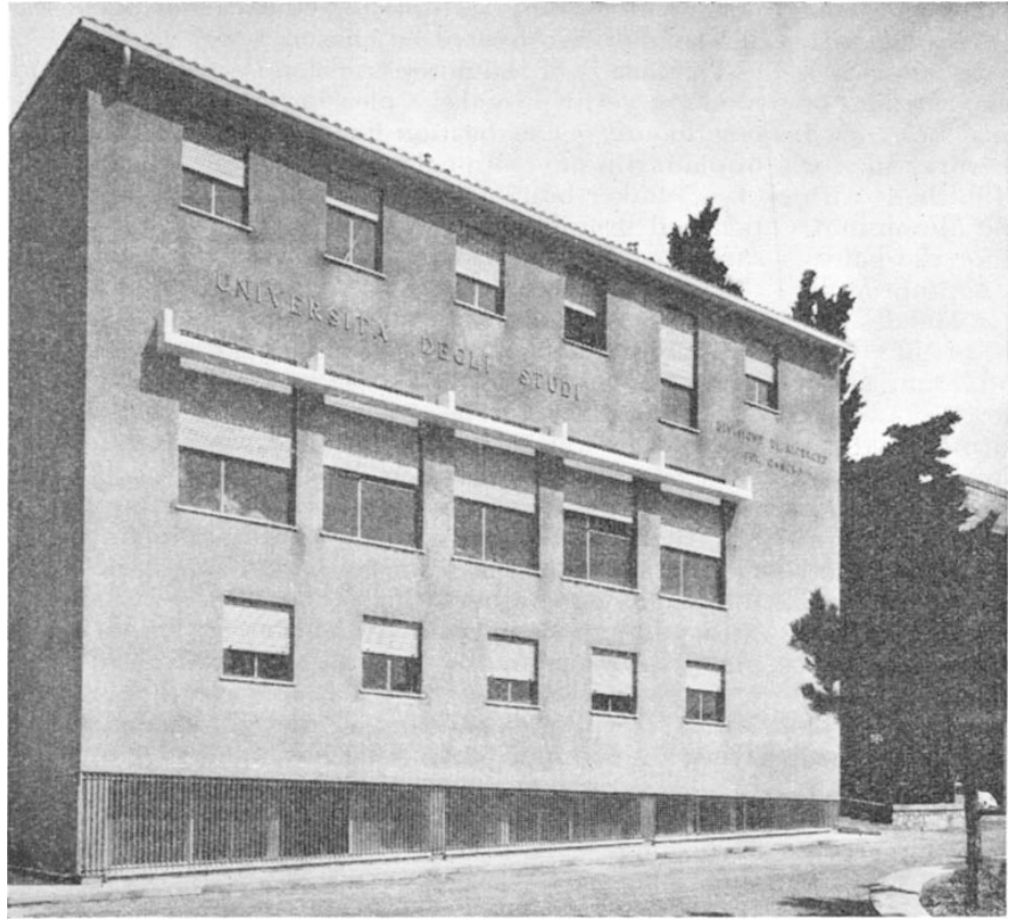

Fig. 1. New Extension of the Division of Cancer Research, University of Perugia

In recent years, much effort has been transferred to the study of causation, behaviour and evolution of mammary tumours in inbred mice. The origins, nature, fate and hormonal control of the hyperplastic alveolar nodules in the mammary glands of virgin and breeding animals carrying the milk factor have been analysed in a series of papers. After the discovery of a new kind of pre-malignant change, the plaque, in hybrid animals, various inbred strains of mice normally bred were investigated to determine the occurrence of plaques. These have been found in two of the three strains investigated. In connexion with these experiments, an analysis of responsiveness and progression of mammary tumours of inbred mice was carried out, which led to the detection of the existence of strain differences in the biological and morphological characters of neoplasms. Finally, a recent extension of these investigations has shown that the strain differences found might be due to differences in the properties of the respective milk factors.

A new field of investigation, cytology, opened at the Division of

colony and laboratories for research in biology and pathology. Later, in the years 1956 and 1957, a programme of improvement was completed with the aid of grants and contributions.

During recent years, investigations have been carried out in the Division by various groups of scientists on different aspects of cancer research. Work on the spreading of metastases in human and experimental tumours has been described in a series of papers dealing with the various facets of the problem. A valuable contribution to the conflicting problems of the morphological precursors of human breast cancer was made by the staff of the Division of Cancer Research working as a unit. In the initial phase, different types of mammary cancer, arising from different lesions, and characterized by a different age at onset, retiological pattern and morphology were detected and classified. It was then shown that the frequency and the latency period were also different for each of these types of cancer. On this basis, an attempt was made to determine the order of importance of the respective morphological precursors; this is still regarded as a useful factor for prognosis. Cancer Research with the conversion of a spontaneous mammary tumour into an ascites tumour. Work on the mitotic rate and chromosomal pattern of this ascites tumour is now in progress.

Recently, it was demonstrated that isoniazid, a drug very widely used in the management of tuberculosis, is carcinogenic for the lungs of $B A L B / c$ mice. Due to its practical importance, this field of investigation has been rapidly extended in order to see whether isoniazid is carcinogenic to other species of animals, whether it is carcinogenic in itself or through some of its metabolites, and how this carcinogenic action may be prevented.

Since its foundation, the Division of Cancer Research has encouraged, within the limits of its facilities, visits of qualified scientists from foreign countries, in order to exchange information and ideas on the work in progress. A large number of such visitors have come during recent years. Several of them delivered lectures. For others, small seminars were organized with the staff. Other visiting scientists have spent several months working at the Division of Cancer Research with members of the staff, in fields of common interest.

\section{THE INTERNATIONAL FEDERATION FOR DOCUMENTATION}

$T$

HE twenty-seventh conference of the International Federation for Documentation was held at Caxton Hall, London, during September 6-16. The Federation has its headquarters at The Hague, and its work on many different problems of documentation is carried on mainly through correspondence, committees and meetings of the Executive
Bureau and a General Assembly held each year in a different country. The large, unrestricted, conference gatherings take place only every three or four years and this was the first to be held in England since 1938. It was attended by more than 500 delegates coming from 38 countries and from all five continents. Aslib, as the British representative 